\title{
Políticas de Desenvolvimento Territorial no Meio Rural Brasileiro: Novas Institucionalidades e Protagonismo dos Atores*
}

\author{
Nelson Giordano Delgado ${ }^{1}$ \\ Sergio Pereira Leite ${ }^{2}$
}

${ }^{1}$ Professor do Programa de Pós-Graduação de Ciências Sociais em Desenvolvimento, Agricultura e Sociedade (CPDA), da Universidade Federal Rural do Rio de Janeiro (UFRRJ) e pesquisador do Instituto Nacional de Ciência e Tecnologia de Políticas Públicas, Estratégias e Desenvolvimento (INCT/PPED/CNPq). Rio de Janeiro, RJ, Brasil (e-mail:

nelsongdelgado@gmail.com)

${ }^{2}$ Professor do Programa de Pós-Graduação de Ciências Sociais em Desenvolvimento, Agricultura e Sociedade (CPDA), da Universidade Federal Rural do Rio de Janeiro (UFRRJ), bolsista de produtividade em pesquisa do Conselho Nacional de Desenvolvimento Científico e Tecnológico (CNPq) e pesquisador do Instituto Nacional de Ciência e Tecnologia de Políticas Públicas, Estratégias e Desenvolvimento (INCT/PPED/CNPq). Rio de Janeiro, RJ, Brasil (e-mail: sergiopereiraleite@uol.com.br)

$\mathrm{O}$ debate atual sobre o desenvolvimento rural no Brasil, e recentemente sobre o desenvolvimento territorial, fundamenta-se, entre outros aspectos, na observação da persistência interligada da pobreza rural e da desigualdade social e regional, e enquadra-se na discussão mais ampla sobre o desenvolvimento econômico e a sustentabilidade. De certa maneira, o conceito de território (concebido como uma escala de ação adequada para empreender políticas públicas diferenciadas) insere-se nesse contexto, refletindo as disputas existentes entre estratégias tão distintas, como aquela que acentua o processo de crescimento econômico com forte vocação exportadora na área agrícola ou, ainda, outra que valorize os processos de desenvolvimento sustentável aliado à ideia de justiça e/ou equidade social.

Assim, a análise dos obstáculos existentes para a articulação de políticas, instituições e a construção de estratégias de desenvolvimento, bem como das soluções encontradas para superá-los, pode ser explorada levando em conta três componentes: (a) os programas governamen-

\footnotetext{
* Este trabalho sistematiza parte dos resultados de pesquisa realizada pelos autores no âmbito do Observatório de Políticas Públicas para a Agricultura (OPPA) / Programa de Pós-Graduação de Ciências Sociais em Desenvolvimento, Agricultura e Sociedade (CPDA), da Universidade Federal Rural do Rio de Janeiro (UFRRJ), que, para sua execução, contou com o apoio e o financiamento do Instituto Interamericano de Cooperação Agrícola (IICA).
}

DADOS - Revista de Ciências Sociais, Rio de Janeiro, vol. 54, n-22, 2011, pp. 431 a 473. 
tais de distintas procedências; (b) as arenas decisórias e os espaços públicos existentes no território; e (c) o empoderamento dos diversos atores e agências institucionais presentes nesses espaços e seus efeitos sobre as possibilidades de articulação das políticas e instituições, e seus reflexos no desenho de projetos estratégicos definidos numa escala que ultrapassa a dinâmica exclusivamente local.

Este artigo busca analisar a recente experiência brasileira de implementação de políticas de desenvolvimento territorial no meio rural, examinando os arranjos institucionais (as novas institucionalidades) construídos para viabilizar o desempenho de ações públicas dessa natureza. Para tanto, são destacadas as dimensões relativas aos processos de gestão social e governança dessas estruturas, bem como ao caráter estratégico dos atores sociais e o protagonismo social que os mesmos exercem, ou não, na implementação das ações nesses espaços públicos diferenciados.

Assim, o presente texto está estruturado em três partes, seguidas de algumas considerações ao final. Na primeira delas são apresentados os programas e seus respectivos desenhos e ossatura que servem de objeto para os nossos propósitos. Na sequência enfatizamos a análise dos processos de gestão social dos territórios à luz da noção de capacidade governativa para, enfim, tratarmos dos alcances e limites dessas novas institucionalidades e da articulação estabelecida entre os atores sociais e desses com as políticas públicas, tomando como referência três estudos de caso desenvolvidos pela pesquisa da qual este artigo deriva ${ }^{1}$.

\section{A EXPERIÊNCIA RECENTE DE DESENVOLVIMENTO TERRITORIAL RURAL NO BRASIL: BREVE RESGATE}

A política brasileira de desenvolvimento territorial aplicada ao setor rural, a cargo da Secretaria de Desenvolvimento Territorial (SDT), vinculada ao Ministério do Desenvolvimento Agrário (MDA), acumulou um significativo conjunto de casos, possibilitando um tratamento mais acurado dos limites e alcances dessa experiência de intervenção pública. Com efeito, o Programa de Desenvolvimento Sustentável dos Territórios Rurais (Pronat), também conhecido como Territórios Rurais de Identidade, está no cerne da formação da própria SDT, ocorrida em 2003, durante o início do primeiro governo Lula. Este programa passou a operar de forma regulamentada em julho de 2005, quando obteve sua chancela formal por intermédio da Portaria no 5, de 18/07/2005. 
Esta portaria, emitida pela SDT, reconhece a seleção, alteração e administração de territórios rurais e garante suporte legal para os Territórios da Cidadania (TC), programa adicional que começou a ser efetivamente executado em 2008.

O conceito de território adotado oficialmente diz respeito a

um espaço físico, geograficamente definido, geralmente contínuo, compreendendo a cidade e o campo, caracterizado por critérios multidimensionais - tais como o ambiente, a economia, a sociedade, a cultura, a política e as instituições - e uma população com grupos sociais relativamente distintos, que se relacionam interna e externamente por meio de processos específicos, onde se pode distinguir um ou mais elementos que indicam identidade e coesão social, cultural e territorial. (Brasil, MDA/SDT, 2005d)

Segundo a SDT a abordagem territorial se justifica por vários aspectos, entre os quais: a) o rural não se resume ao agrícola; b) a escala municipal é muito restrita para o planejamento e organização de esforços visando à promoção do desenvolvimento e a escala estadual é excessivamente ampla; c) a necessidade de descentralização das políticas públicas; d) o território é a unidade que melhor dimensiona os laços de proximidade entre pessoas, grupos sociais e instituições, estabelecendo iniciativas voltadas para o desenvolvimento.

A intenção dos programas é garantir que os processos de desenvolvimento envolvam múltiplas dimensões, cada qual contribuindo de uma determinada maneira para o conjunto do território em diferentes áreas, como a econômica, sociocultural, político-institucional e ambiental.

Na abordagem dos territórios rurais de identidade, não é incomum referir-se também à dimensão "cultural". Isto é, os territórios rurais fundamentar-se-iam na existência de um corpo de normas (simbólicas ou não) específicas da sociedade local, ou seja, aproximando-se da ideia uma "identidade territorial" (Echeverri, 2009). No entanto, a construção dessa "identidade" é atributo de alguns territórios, mas não de todos. Entre os critérios utilizados pela SDT para identificar os territórios rurais estão: i) conjunto de municípios com até 50 mil habitantes; ii) conjunto de municípios com densidade populacional menor que 80 habitantes $/ \mathrm{km}^{2}$; iii) maior concentração do público prioritário do MDA (agricultores familiares, famílias assentadas pela reforma agrá- 
ria, agricultores beneficiários do reordenamento agrário, o que caracteriza maior intensidade de demanda social); iv) conjunto de municípios já organizados em territórios rurais de identidade; v) conjunto de municípios integrados com os Consórcios de Segurança Alimentar e Desenvolvimento Local (Consad), do Ministério do Desenvolvimento Social (MDS), e Mesorregiões, do Ministério da Integração Nacional.

Até o presente foram identificados 164 territórios rurais, distribuídos em todas as regiões brasileiras, vinculados ao MDA por meio da SDT. Propostas de novos territórios ou modificação de territórios já estabelecidos podem surgir em instâncias locais, devendo ser remetidas aos Conselhos Estaduais de Desenvolvimento Rural Sustentável (CEDRS) para fins de análise e manifestação, que posteriormente as encaminha à SDT. Também nesse sentido, os projetos de desenvolvimento para os territórios rurais surgem nos fóruns locais - os Conselhos de Desenvolvimento Territorial (Codeters), e são apoiados pela SDT, por intermédio do Condraf (Conselho Nacional de Desenvolvimento Rural Sustentável).

Durante o processo de identificação dos territórios rurais, o governo entendeu que alguns territórios apresentavam-se economicamente mais fragilizados que outros e, com isso, necessitavam de uma atenção emergencial com ações ainda mais articuladas. A partir dessa percepção surge o Programa Territórios da Cidadania, lançado em 2008, que tem o mesmo referencial conceitual dos territórios rurais sendo amparado também pela mesma portaria, mas com uma gestão bem mais complexa. Resumidamente, foi do conjunto de territórios rurais que o governo, em geral, selecionou os territórios da cidadania. A prioridade era atender territórios que apresentassem baixo acesso a serviços básicos, índices de estagnação na geração de renda e carência de políticas integradas e sustentáveis para autonomia econômica de médio prazo.

O Programa Territórios da Cidadania era uma das ações destinadas a reduzir as desigualdades propostas pela Agenda Social do Governo Federal. Seu objetivo é a "superação da pobreza e geração de trabalho e renda no meio rural por meio de uma estratégia de desenvolvimento territorial sustentável". Especificamente, o programa visa à promoção da inclusão produtiva das populações pobres dos territórios, por meio do planejamento e integração de políticas públicas. Também se propõe ampliar a participação social e garantir a universalização dos programas básicos de cidadania. O programa abrangia, até o fim de 2008, 60 
territórios, mas foi ampliado para 120 territórios da cidadania em 2009. Segundo a Mensagem ao Congresso Nacional 2009, este programa constituía-se "na principal estratégia do governo para redução das desigualdades no meio rural, por meio de integração de políticas públicas".

Os critérios utilizados na seleção dos territórios da cidadania foram: i) menor IDH (Índice do Desenvolvimento Humano); ii) maior concentração de agricultores familiares e assentados da Reforma Agrária; iii) maior concentração de populações quilombolas e indígenas; iv) maior número de beneficiários do Programa Bolsa Família; v) maior número de municípios com baixo dinamismo econômico; vi) maior organização social; vii) pelo menos um território por Estado da Federação (Brasil, MDA/SDT, 2007).

Enquanto o Pronat apresentava um esquema de gestão exclusivamente centrado na SDT / MDA, vinculando os diferentes colegiados territoriais ao Ministério, o processo de gestão do Programa Territórios da Cidadania estabelecia um tripé: Comitê Gestor Nacional, Comitês de Articulação Estadual e os Colegiados Estaduais. O Comitê Gestor Nacional é formado por representantes de 19 (em 2010 com 22) ministérios, sendo a coordenação geral executada pelo MDA. Este comitê tem por atribuição aprovar diretrizes, adotar medidas para execução do programa, avaliá-lo e definir novos territórios. A coordenação é do MDA, mas a articulação era feita, até dezembro de 2010, pela Casa Civil e o monitoramento do programa, realizado pelo NEAD (Núcleo de Estudos Agrários e Desenvolvimento Rural).

Os comitês de articulação estadual são consultivos e propositivos. Procuram articular órgãos federais, estaduais e representações das prefeituras dos municípios envolvidos nos territórios. Visam apoiar a organização e mobilização dos colegiados, fomentar a articulação e integração das diversas políticas públicas nos territórios, acompanhar a execução do programa, auxiliar na sua divulgação e apresentar sugestões de novos territórios e ações.

Os colegiados territoriais são compostos por representantes das três esferas de governo e da sociedade em cada território. Em comparação com a composição dos territórios rurais, amplia-se no Programa Territórios da Cidadania a estrutura desses colegiados. Eles possuem uma coordenação executiva de composição paritária, diferentemente da composição dos Codeters do Pronat, na qual prevalece a participação 
de representantes da sociedade civil (em geral com dois terços dos componentes dessas arenas).

Entre as atribuições dos colegiados territoriais destacam-se: i) divulgar as ações do programa; ii) identificar demandas locais para o órgão gestor priorizar o atendimento (de acordo com critérios, sistemas de gestão pré-estabelecidos, especificidades legais e instâncias de participação existentes)b; iii) promover a interação entre gestores públicos e conselhos setoriais; iv) contribuir com sugestões para qualificação e integração de ações; v) sistematizar as contribuições para o Plano Territorial de Ações Integradas; vi) exercer o controle social do programa.

Apesar de excessivamente normativa, a apresentação acima é importante para compreendermos a mudança operada na formatação das políticas orientadas aos territórios rurais e na maneira de pensar o processo de gestão social dos mesmos. Essa reformulação no arranjo institucional da política (reforçando sua dimensão polity) tem reflexos diretos na forma com que os diferentes atores se envolvem no programa (rebatendo nos processos de participação social, na constituição de arenas consultivas e decisórias, no acompanhamento, monitoramento e controle público das ações implementadas etc.).

No caso dos territórios da cidadania, diferentemente dos rurais, o desafio torna-se maior, pois envolvem diferentes ações setoriais oriundas de distintos ministérios, cujo exercício de articulação se dará efetivamente na escala territorial, complexificando o processo de gestão social. Muito mais que a mera somatória de ações e dotações orçamentárias dos ministérios sobre um mesmo espaço social, trata-se de pensar a lógica da territorialização e governança de políticas a partir de um encontro de ações bottom-up, pelos atores locais - agora não necessariamente agrários - com aquelas top-down, também não necessariamente setoriais.

Antes de avançarmos nessas questões, repassemos os marcos que têm balizado o processo de intervenção pública na área, tomando como referência a institucionalidade operada no âmbito do Pronat ${ }^{2}$.

Na perspectiva da normatização da política ganham destaque dois processos: a descentralização das políticas públicas e o empoderamento dos atores locais. Ambos os atributos são identificados como centrais à lógica da ação pública, na medida em que se supõe que sua efetiva implantação fortalecerá os processos de participação social (alia- 
dos aos mecanismos de governança democrática e transparência e/ou accountability da política territorial). Nesse sentido a participação social garantiria a vigência dos princípios que marcariam a diferença entre a "velha" experiência de planejamento do desenvolvimento rural (muito em voga nas décadas de 1970 e 1980, incentivada pelos programas financiados por agências multilaterais) e a recente iniciativa de planejamento e desenvolvimento territorial. Para tanto, o documento governamental propõe a realização de um ciclo de gestão social, em boa medida lastreado nas policy analysis dedicadas ao exame dos policy cycles (Flexor e Leite, 2007; Frey, 2000).

Para o que nos interessa neste trabalho, a implantação da política previa a constituição de arenas específicas para o alcance dos objetivos propostos pelo Pronat. É bom lembrar que a própria construção de espaços públicos para o exercício do diálogo e a tomada de decisões, como é o caso dos colegiados territoriais, consiste, ela própria, numa diretriz de intervenção governamental que autores como Frey (2000) irão nomear de políticas constitutivas (ao lado das políticas distributivas, regulatórias e redistributivas), redesenhando a ossatura público-governamental para a prática dos instrumentos de política (policies) derivados dessa nova institucionalidade política (polity) que, por sua vez, resulta das negociações políticas (politics) que dão sustentação ao novo arcabouço sobre o qual o programa é operado.

Assim, a implantação desses espaços no nível territorial consiste numa peça estratégica para a prática da política de gestão social e de governança territorial. Com efeito, as Resoluções 48 e 52 do Condraf (Brasil, MDA/Condraf, 2004 e 2005) já informavam a "efetivação e democratização" dos conselhos como mecanismo para assegurar o processo de participação social e propor uma efetiva política de desenvolvimento, "eliminando interferências político-partidárias e das oligarquias locais no processo decisório" (Res. Condraf 48, alínea d das considerações iniciais). Dessa forma, estes espaços públicos deveriam contemplar a representatividade, a diversidade e a pluralidade dos atores envolvidos (idem, ibidem, Art. 1을 ${ }^{3}$, atentando para duas entre as diversas recomendações existentes no âmbito da resolução: a) buscar a normatização dos conselhos (especialmente na forma de leis - municipais, estaduais e/ou federais), assegurando a continuidade das suas ações; e b) garantir que, no mínimo, 50\% das vagas dos conselhos sejam ocupadas por representantes da sociedade civil organizada ligada à agricultura familiar (os demais 50\%, ou menos, dos postos seriam dirigidos para 
representantes do setor público, de organizações para-governamentais e outros setores da sociedade civil não relacionados à agricultura familiar).

Na proposição normativa do documento da SDT, essas arenas territoriais comportam três espaços diferenciados, sendo que sua efetiva denominação e funcionamento seria objeto da especificidade de cada um dos territórios criados: plenário (com a participação de todos os representantes do colegiado), núcleo dirigente ou diretivo, de caráter paritário e responsável pela implementação das ações da plenária e do plano territorial, e o núcleo técnico, com a missão de subsidiar o funcionamento das instâncias colegiadas aportando conhecimento e expertise sobre temas e áreas indicados para tanto.

Outro instrumento correlato ao tema aqui discutido é aquele relativo ao controle social dos processos e políticas de desenvolvimento territorial, rebatendo diretamente na capacidade de governança das políticas públicas.

Nessa perspectiva o monitoramento e a avaliação, em especial dos Planos Territoriais de Desenvolvimento Rural Sustentável (PTDRS), seriam os dois instrumentos previstos pelo mecanismo de controle social. Particularmente, merece destaque, no texto oficial, a ideia de que o controle, operado como instrumento de gestão e governança territorial, teria principalmente o objetivo de garantir a maior eficiência no uso dos recursos públicos, visando atingir os indicadores de desenvolvimento programados (Brasil, MDA/SDT, 2005a).

Deve-se destacar que os instrumentos de monitoramento e de avaliação (seja na escala do desenvolvimento territorial propriamente dita, seja na escala de programas e projetos específicos) passem a operar a partir de processos participativos, abastecidos por informações pertinentes e pautados por indicadores que reflitam as aspirações e expectativas depositadas na perspectiva do desenvolvimento do território.

Apesar do sofisticado desenho técnico-instrumental que informa o contexto no qual se produz e implementa o processo de gestão social dos territórios, é interessante ressaltar, para voltarmos ao documento original da SDT, que todos esses mecanismos de política só teriam sentido com sua plena utilização pelos atores objeto da política, o que nos leva a aprofundar o exame dessa experiência à luz das questões alinhavadas nos próximos tópicos. 


\section{CAPACIDADE GOVERNATIVA, GESTÃO SOCIAL DOS TERRITÓRIOS E ARRANJOS INSTITUCIONAIS: ENTRE NORMAS E PRÁTICAS SOCIAIS}

Recorrendo a Hirschman (1984), acreditamos que os mecanismos de gestão social ${ }^{4}$ e capacidade governativa ${ }^{5}$ desses espaços podem assumir configurações distintas, tempos e movimentos específicos e processos de desenvolvimento que não obedecem às mesmas sequências, diferenciando-se entre si, o que o autor denominou de processo das sequências invertidas. Aqui, este tipo de afirmação implica problematizar a linearidade do ciclo de gestão social dos territórios na medida em que, em função das suas particularidades, a ordem e a velocidade das etapas podem não obedecer a um mesmo sequenciamento. Isso não invalida a tentativa da administração pública de normatizar a política de intervenção e gestão territorial, homogeneizando procedimentos. No entanto, entre a normatização e a prática é necessário manter certa flexibilidade, adequando tais parâmetros ao contexto histórico, social, econômico, político e cultural no qual se firmam as diferentes experiências de desenvolvimento territorial rural no Brasil.

Assim, as expectativas dos resultados a serem alcançados com relação ao tema aqui tratado - gestão social territorial - presentes nos documentos oficiais devem ser interpretadas numa perspectiva relativa, para a qual concorrerão afirmativa e/ou contraditoriamente os diferentes móveis dos tabuleiros territoriais. No plano oficial, particularmente em relação ao Pronat, espera-se que a implementação da política atravesse as seguintes etapas, naquilo que foi denominado "macroprocesso da gestão social": i) sensibilização e mobilização; ii) visão de futuro; iii) diagnóstico; iv) planejamento; v) arranjos institucionais; vi) organização para a execução de planos; vii) direção para a execução dos planos; viii) monitoramento e avaliação (Brasil, MDA/SDT, 2006a, 2006b).

Um exame mais acurado sobre a práxis da gestão social territorial requer a observação de alguns aspectos mais críticos que, à luz da experiência do Pronat, serão tratados a seguir. Documento elaborado a pedido do Condraf, tendo como referência uma sistematização de diversos estudos sobre institucionalidade, gestão nas políticas e instâncias relacionadas ao desenvolvimento rural no país (Brasil, MDA/Condraf, 2005a), apresenta tópico relativo às "bases territoriais e institucionais das diferentes esferas de gestão social", subdividido em quatro aspectos. 
No primeiro ("abrangência e interação das ações"), constata-se que os estudos examinados convergiram para o fato de que: a) a interação entre os diversos atores sociais nos Conselhos Municipais de Desenvolvimento Rural (CMDRs) ainda era bastante baixa; b) a definição das linhas de atuação (centradas em atividades agrícolas) e a gestão dos planos de trabalho ficava a cargo da equipe técnica dos órgãos públicos envolvidos; c) a interação observada entre os municípios de uma determinada região dava-se mais pela competição do que pelo estabelecimento de parcerias, como também eram precárias as articulações entre os entes públicos das esferas municipal, estadual e federal de governo.

No segundo aspecto ("amplitude e enfoque dos debates"), as convergências sistematizadas apontavam para o fato de que os Planos Municipais de Desenvolvimento Rural (PMDRs) possuíam mais uma "lista de compras" do que propriamente um projeto de desenvolvimento, além de que a atuação dos conselhos estava primordialmente direcionada à resolução de problemas pontuais, perdendo visão estratégica de médio e longo prazos e impedindo diagnóstico mais profundo sobre os impactos da política nas economias locais.

No terceiro aspecto ("continuidade e descontinuidade das ações"), os documentos analisados concordavam que as ações dos CMDRs limitavam-se ao uso dos recursos do Programa Nacional de Fortalecimento da Agricultura Familiar (Pronaf), criando uma dependência da atuação dos conselhos frente a uma dada política pública, que oscila de governo para governo.

Finalmente, o quarto aspecto sublinhado ("mecanismos de apoio ao funcionamento da institucionalidade") observava a falta de infraestrutura e apoio para o funcionamento dos conselhos e, por conta disso, sua dependência em relação às instalações e meios oferecidos pelas prefeituras municipais.

Outros estudos ressaltam que a herança da cultura política manifestada na centralização dos processos de tomada de decisão e no clientelismo das relações constitui-se num obstáculo central para a conformação de um ambiente institucional capaz de planejar o desenvolvimento territorial, coordenando e integrando uma diversidade de atores sociais, ações estratégicas e projetos específicos. Dessa forma, privilegiam-se os segmentos mais favorecidos e/ou empoderados, criando-se distorções nos objetivos da política, descontinuidade de ações e a centralização das decisões em poucos agentes. Muitas dessas antigas prá- 
ticas não foram eliminadas e são transpostas para os territórios, segregando municípios e grupos sociais que não têm força representativa (Couto e Rocha, 2006:9).

Em parte considerável dos processos de ampliação da participação em políticas públicas, o conflito é subestimado ou "evitado" como forma de se preservar a "harmonia" entre os diferentes grupos que compõem a arena decisória e, portanto, a sua estabilidade política. No entanto, o embate de opiniões e de posições e a resolução (nem sempre possível) dos conflitos é uma etapa constituinte e intransferível do processo participativo, e reforça a importância de que sejam previstos e garantidos mecanismos de incentivo à participação, que assegurem a representatividade dos grupos sociais e a transparência dos processos decisórios.

O reconhecimento e o enfrentamento dos conflitos, mesmo aqueles existentes no interior dos grupos alinhados com os interesses da agricultura familiar, constituem elemento fundamental para a dimensão governativa territorial (Hirschman, 1984). A eliminação do conflito, muitas vezes, bloqueia o surgimento de novas dinâmicas e compromete a ampliação dos canais democráticos de participação, na medida em que tende a privilegiar aqueles grupos sociais que possuem posição privilegiada na estrutura de poder local. É relevante considerar que a diferença no grau de representatividade dos variados atores (segundo sua capacidade de articulação política e o conhecimento do funcionamento dos processos burocráticos de acesso a recursos públicos) pode vir a gerar formas distintas de participação e de intervenção desses grupos sociais no processo de gestão, produzindo configurações específicas no momento da aplicação dos recursos disponibilizados em nível territorial (Couto e Rocha, 2006:11).

Contudo, não se pode deixar de reconhecer o êxito que a política da SDT logrou na ampliação da visibilidade de certos grupos sociais (particularmente aqueles que já estavam organizados em entidades de representação) que até então não eram considerados (ou apenas marginalmente) nos processos de desenvolvimento rural e territorial. Os investimentos realizados em capacitação de lideranças e nas atividades de mobilização contribuíram para a ampliação dos canais de acesso à informação. Adicionalmente, a política territorial conferiu o efetivo reconhecimento dessas populações como público estratégico para o desenvolvimento territorial, dando-lhes mais visibilidade e elevando 
seu capital político, uma vez que se tornam mais capazes de influenciar a condução das políticas de desenvolvimento.

A experiência do Território da Borborema (na Paraíba) pareceu-nos ilustrativa da mudança operada pela gestão da política territorial na aplicação dos recursos existentes: de uma situação inicial na qual os mesmos se concentravam no grupo de atores articulados pelo polo sindical para outra, mais distribuída, onde foi contemplado adicionalmente o fórum de assentados e os atores mais próximos à região do semiárido (Bonnal e Piraux, 2007; Delgado e Zimmermann, 2008b).

Favareto (2008), entre outros autores, tem defendido uma mudança substancial no arco de atores que devem ser incorporados à dinâmica territorial evitando o risco que o empoderamento de atores mais organizados signifique uma apropriação desproporcional dos recursos financeiros. O autor afirma, ainda, que a consolidação de um projeto efetivamente territorial não pode se restringir a um projeto eminentemente agrícola. Essas questões talvez fiquem mais evidentes no caso da experiência dos Territórios da Cidadania do que nos Territórios Rurais de Identidade. A ampliação de atores, segundo o autor, incluiria aqueles mais desorganizados e próximos à base do público preferencial de políticas do MDA, como também os segmentos não rurais e o empresariado local. Aqui é preciso ter um pouco de cautela, visto que os processos políticos implicam uma certa construção de campos hegemônicos, como evidenciaremos no tópico seguinte, e é quase impossível pensarmos na emergência de propostas territoriais consensuais com arco tão diferenciado de interesses. Nesse sentido, se a necessidade de reconfigurar os campos de poder se faz presente, é preciso avaliar bem os instrumentos disponíveis para tanto (como o fortalecimento das organizações locais) e o perfil de atores estratégicos com os quais se irá desenvolver o processo de gestão. Dar visibilidade a atores mais vulneráveis para os quais se espera um acesso ao conjunto de políticas (e recursos) é bem diferente de atribuir espaços mais significativos a um grupo de atores historicamente caracterizados por posturas conservadoras quanto às esferas de governança democrática e cuja atuação tenha se dado primordialmente na base de concentração de ativos (políticos, econômicos, fundiários).

Por outro lado, nunca é demais relembrar que a vigência dos processos e políticas de gestão territorial deve comportar uma recuperação da bagagem histórica sobre os quais os mesmos se assentam, o caráter ati- 
vo da participação dos atores e, em particular, da própria intervenção do Estado. Brandão (2007:49-50) ajuda-nos a avançar sobre esse ponto:

a necessidade da "territorialização" das intervenções públicas é tomada como panaceia para todos os problemas do desenvolvimento. Assevera-se, de forma velada ou explícita, que todos os atores sociais, econômicos e políticos estão cada vez mais plasmados, "diluídos" (subsumidos), em um determinado recorte territorial. Na verdade, parece existir uma opção por substituir o Estado ("que se foi"), por uma nova condensação de forças sociais e políticas (abstrata) que passa a ser chamada de território. Muitas vezes estão ausentes ou 'mal abstraídas' questões estruturais. Propugnam-se receitas genéricas, descurando, por exemplo, das especificidades de um contexto de país subdesenvolvido, continental, periférico e com uma formação histórica da escala local bastante peculiar. Lança-se mão de repertórios de boas práticas bem catalogadas, fruto de um esforço de pesquisa de criação de inventários de experiências de desenvolvimento territorial. O território passa a ser visto como o grande elemento repositório, condensador e, ao mesmo tempo, regulador autômato de relações, dotado da propriedade de sintetizar e encarnar projetos sociais e políticos. [...] À ação pública caberia apenas animá-lo e sensibilizá-lo, construindo confiança e consenso duradouros. É bom lembrar que tal consenso surge como pressuposto e não como propósito a ser construído. Negligencia-se, claramente, o papel, por exemplo, do Estado na provisão de infraestrutura, tanto hard, quanto soft, que penso, ainda são importantes fatores de estruturação de dinâmicas. [...] O território que deveria ser visto como ambiente politizado, em conflito e em construção é posto como ente mercadejado e passivo, mero receptáculo. O que é fruto de relações sociais aparece como relação entre objetos. Há uma coisificação e o território parece ter poder de decisão, transformado em sujeito coletivo.

Ou seja, é preciso pensar a dinâmica territorial de forma não autárquica, mesmo que se valorize os procedimentos de desenvolvimento endógeno dessas experiências. Isso implica uma gestão e governança mais complexa intra e interterritórios, bem como entre os diferentes níveis por onde circulam os atores.

Assim, o processo de governança e gestão social carrega dois aspectos que devem ser melhor examinados quanto aos limites e alcances que tal perspectiva assume no desenvolvimento territorial: a) é preciso pensar sob qual arranjo institucional a experiência de gestão se desenvolve. Se a perspectiva ofertada é aquela que enfatiza a política territo- 
rial como uma política de combate à pobreza, os instrumentos e as práticas relativas à gestão social assumirão certamente uma performance muito diferente quando a ênfase estiver centrada na construção de cadeias produtivas dispostas em "arranjos" locacionais determinados; b) o outro ponto crucial para definir o funcionamento da gestão territorial refere-se à forma pela qual foram mobilizados os atores e escolhidos os segmentos sociais participantes. Isso implica, necessariamente, tratar o tema da gestão sob a emergência das novas institucionalidades das políticas públicas, em especial aquelas evidenciadas pelo Programa Territórios da Cidadania, tarefa à qual nos dedicaremos a seguir.

\section{GESTÃO DE POLÍTICAS PÚBLICAS DE DESENVOLVIMENTO RURAL NO CONTEXTO DAS NOVAS INSTITUCIONALIDADES TERRITORIAIS. ANÁLISE COMPARADA DOS TERRITÓRIOS DA CIDADANIA INVESTIGADOS}

A pesquisa de campo operada no estudo que deu origem a este artigo foi realizada em três Territórios da Cidadania: Baixo Amazonas no Pará, Borborema na Paraíba e Noroeste Colonial no Rio Grande do Sul. De modo geral, em cada um desses territórios buscou-se compreender (1) a caracterização socioeconômica do meio rural e da estrutura de poder prevalecente; (2) as experiências políticas, sociais e institucionais locais que precederam à criação do território e que influenciaram a sua conformação institucional; (3) as características assumidas pela institucionalidade territorial, suas potencialidades e limites; (4) os atores sociais participantes na institucionalidade e na gestão da política pública territorial, com destaque para a consideração dos projetos territoriais apresentados e aprovados pelo colegiado territorial; e (5) a existência ou não de protagonismo social no território e as características assumidas pela dinâmica institucional no mesmo ${ }^{6}$.

\section{As Novas Institucionalidades Territoriais}

Comecemos com um esclarecimento conceitual. Por novas institucionalidades estamos entendendo o conjunto de instituições (regras de funcionamento, normas existentes - explícitas e implícitas - e organizações colegiadas) criadas pelos programas federais para conduzir a gestão social, a governança e a escolha dos projetos estratégicos da política territorial, com a participação de representantes do Estado e da sociedade civil ${ }^{7}$. Esta nova institucionalidade territorial é, então, uma aproximação ao que foi chamado, na literatura recente, de "espaços públicos de participação", nos quais as decisões sobre a abrangência 
do conceito de público e sobre as políticas públicas - em geral setoriais, mas não apenas - não se restringem exclusivamente ao âmbito dos atores ou agentes estatais, mas são efetivadas através de sua inter-relação com atores da sociedade civil representados nesses espaços ${ }^{8}$.

Note-se que esta perspectiva tem como objetivo democratizar a gestão e o controle da política pública - não sendo coincidência que ganhou importância política no Brasil com a redemocratização do país a partir da metade da década de 1980 - na medida em que não circunscreve o público simplesmente ao estatal e, com isto, reconhece que decisões sobre ação e política públicas podem ser tomadas conjuntamente em espaços públicos, precipuamente criados para tal e com regras de funcionamento estabelecidas, no qual participam representantes do Estado e da sociedade civil $^{9}$. Visa também melhorar a qualidade da ação e da política do Estado, na expectativa de que a criação de espaços e de mecanismos públicos que permitam maior interação dos gestores estatais com os usuários da ação e da política estatais, na perspectiva tanto de sua implementação como de seu controle, tenderá a estimular a obtenção de resultados mais qualificados.

Os Territórios da Borborema/PB e do Baixo Amazonas/PA foram criados originalmente no Programa Territórios Rurais de Identidade e foram posteriormente incluídos no Programa Territórios da Cidadania. O Território do Noroeste Colonial/RS já nasceu como Território da Cidadania sem ter existido previamente como território rural de identidade, o que trouxe, em nossa opinião algumas consequências para o protagonismo social neste território, como veremos mais adiante.

No Pronat duas grandes esferas sociais estão privilegiadamente contempladas na institucionalidade territorial estabelecida: o Estado e a sociedade civil. De modo geral, as organizações pertencentes a essas esferas e que estão envolvidas na composição dos colegiados são aquelas reconhecidas como tendo influência no território, tais como prefeituras, movimentos sociais, sindicatos, ONGs, agências governamentais estaduais e federais, conselhos, entre outros. A porcentagem de membros da sociedade civil e do Estado varia conforme os colegiados, mas a maior parte das experiências existentes é ou de paridade entre ambos ou de composição dois terços sociedade civil e um terço poder público.

É importante lembrar, como assinalamos anteriormente, que a abordagem territorial para as políticas de desenvolvimento rural foi adotada, 
a partir de 2003, pela recém-criada SDT/MDA do primeiro governo Lula, em substituição à política dos governos anteriores que tinha o município como seu marco de referência principal. Esta mudança foi particularmente impactante pela extinção do Pronaf Infraestrutura e Serviços, programa que canalizava recursos a fundo perdido para municípios selecionados e que era implementado pelas prefeituras com a supervisão e o controle feitos pelos Conselhos Municipais de Desenvolvimento Rural (aos quais se acrescentava o adjetivo Sustentável em alguns municípios), os conhecidos CMDRs, criados para tal fim ${ }^{10}$.

A extinção do Pronaf Infraestrutura e Serviços e a canalização dos recursos que dispunha para a política territorial reduziram o montante de financiamentos recebido pelos municípios anteriormente contemplados pelo programa, fazendo com que prefeituras e CMDRs perdessem poder com a mudança de política, o que induziu muitos prefeitos municipais a resistirem e se oporem à nova política territorial e deixou os CMDRs deslocados e fora de lugar em decorrência da transição para a nova institucionalidade territorial.

No caso do Programa Territórios da Cidadania, oficializado em 2007, a institucionalidade territorial está fundamentalmente composta, como nos territórios rurais de identidade, por representantes do Estado e da sociedade civil, com uma composição de participação que se assemelha a deste último. No entanto, como informamos no primeiro tópico, há uma diferença importante. Nos territórios da cidadania, a distribuição entre os participantes do Estado e da sociedade civil deve ser, em princípio, paritária, de modo que sua orientação exige uma composição ampliada em relação ao que são os colegiados formados nos territórios rurais de identidade. Ou seja, nos territórios da cidadania a recomendação é de que a presença do Estado seja maior do que nos territórios rurais de identidade, e que se expresse por meio da participação mais intensa de representantes das três esferas de governo (federal, estadual e municipal).

Esta orientação é coerente com os objetivos gerais do programa, que pretende a superação da pobreza rural e a conquista da cidadania em territórios selecionados, por meio da mobilização de diferentes ministérios setoriais e agências governamentais no sentido de planejarem suas ações para que as políticas públicas incidentes nesses territórios sejam implementadas de forma articulada e integrada. 
Em termos concretos nos territórios da cidadania que investigamos, não obstante as dificuldades existentes para a sua execução, a importância e o volume de recursos anunciados pelo programa provocaram uma nova mobilização em torno da política territorial, especialmente pelas prefeituras municipais que passaram a demonstrar um maior interesse em participar da institucionalidade territorial. Em contraposição, a exigência de paridade de participação com os membros do Estado assustou inicialmente os representantes da sociedade civil, em função da rejeição anterior e do novo "oportunismo" demonstrado por muitos prefeitos, além do risco de que a institucionalidade territorial pudesse assumir um contorno eminentemente governamental. No entanto, foi possível perceber na pesquisa de campo que, apesar de continuarem a existir, esses temores reduziram-se com o passar do tempo frente a um problema central da dinâmica institucional que é o reconhecimento de que, sem a participação, a compreensão e o envolvimento dos atores governamentais, a política territorial não tem condições de avançar, de modo que sua presença no colegiado e nas demais instâncias da institucionalidade territorial significa um desafio e um aprendizado indispensáveis para a melhoria da qualidade e da efetividade da política territorial.

O Território da Cidadania da Borborema / PB surgiu como território rural em 2003, participando do Programa Territórios Rurais de Identidade da SDT/MDA. Em 2008, transformou-se em Território da Cidadania. A institucionalidade territorial na Borborema fundou-se inicialmente na existência do Fórum de Desenvolvimento Territorial Sustentável da Borborema, denominação assumida neste território pelo colegiado territorial, sua instância mais importante de deliberação acerca da política territorial, em particular por meio da aprovação de projetos de desenvolvimento territorial a serem financiados com recursos da SDT/MDA.

Ao longo da evolução do Pronat, o Fórum foi estruturado em um Núcleo de Coordenação, com o objetivo de articular atores e organizações no processo de desenvolvimento territorial e na elaboração e na implementação do PTDRS, um Núcleo Técnico, estruturado em grupos temáticos, que apoia tecnicamente o Fórum e o Núcleo de Coordenação, e uma Plenária Geral, de que participam todos os membros do Fórum e que é seu órgão máximo de decisão. Por fim, existe o cargo de articulador(a) territorial, criado e financiado pela SDT / MDA para fortalecer a articulação territorial e assumido por uma das organizações locais que 
fazem parte do Fórum. De modo geral, os atores territoriais (nos três territórios estudados) consideram o a poio administrativo, técnico e financeiro dado a esta figura muito insuficiente para dar conta de todas as tarefas envolvidas no processo de articulação territorial.

No Fórum de Desenvolvimento Territorial da Borborema, estão fundamentalmente representadas as esferas sociais do Estado e da sociedade civil, não existindo na representação da sociedade civil organizações ou associações que expressem os interesses dos atores do mercado. Isto ocorre tanto no período em que predominava o Programa Territórios Rurais de Identidade, quanto após a criação do Programa Territórios da Cidadania. Na verdade, os membros do Fórum podem ser agrupados em três grandes grupos: (1) a representação do Estado, através das prefeituras municipais e de outras agências governamentais (como Empresa Estadual de Assistência Técnica e Extensão Rural - Emater; Empresa Brasileira de Pesquisa Agropecuária - Embrapa; Instituto Nacional de Colonização e Reforma Agrária - Incra; universidades; Banco do Nordeste etc.); (2) a representação da sociedade civil, na qual se destacam os sindicatos de trabalhadores rurais (principalmente ligados ao Polo Sindical da Borborema); outros movimentos sociais e organizações de agricultores (Movimento dos Trabalhadores Rurais Sem Terra - MST; Movimento dos Pequenos Agricultores - MPA; Fórum dos Assentados; movimentos agroecológicos e de agricultores experimentadores etc.); e organizações não governamentais, como a Assessoria e Serviços em Projetos de Tecnologia Alternativa - AS-PTA, associações etc.; e (3) a representação de espaços públicos municipais de participação, basicamente os CMDRs de vários municípios, que como tal não fazem parte nem do Estado, nem da sociedade civil estrito senso. A grande diferença do Fórum nos dois períodos é a de que no território da cidadania a representação do Estado foi ampliada, especialmente por meio de uma "bancada" mais numerosa de prefeitos.

O Território da Cidadania do Noroeste Colonial/RS, como já destacamos, foi criado em 2008 para fazer parte do Programa Territórios da Cidadania. Surgiu, portanto, como um território da cidadania sem ter passado pela experiência prévia de território rural de identidade, o que atesta sua breve existência e a pouca experiência dos atores locais com o manejo e as exigências da política territorial. Uma singularidade importante deste território, em relação aos demais territórios existentes no país, é que foi instituído em um contexto no qual já existia, desde o início da década de 1990, uma institucionalidade regional concebida 
pelo governo estadual, com base na divisão do Estado do Rio Grande do Sul em conselhos regionais de desenvolvimento, os coredes ${ }^{11}$. $\mathrm{Na}$ região que estamos considerando foi criado originalmente o Corede Noroeste Colonial, incluindo 32 municípios pertencentes a duas subregiões com características socioeconômicas distintas, problemas específicos e diversidade de atores sociais, as chamadas "região de Ijuí" e "região Celeiro". Como consequência de antigas reivindicações, em especial dos representantes da região Celeiro, em janeiro de 2008 o Corede original foi desmembrado em dois: o atual Corede Noroeste Colonial (na "região de Ijuí", com 11 municípios) e o novo Corede Celeiro (na "região Celeiro", com 21 municípios).

Apesar disso, a configuração que o Território da Cidadania Noroeste Colonial assumiu (com 34 municípios) ao final do ano de 2008, quando foi escolhido para fazer parte do Programa Territórios da Cidadania do Governo Federal, representou um novo reagrupamento dos dois Coredes "sub-regionais" e uma certa "volta ao passado" com a retomada da composição do Corede Noroeste Colonial vigente até o início de 2008, acrescido de dois municípios, Cruz Alta e Boa Vista do Cadeado, situados em outro corede. Dentre as razões aparentes para isso, a mais importante parece ser a de que este foi o arranjo político considerado indispensável para garantir a criação de um território da cidadania na região Noroeste Colonial - onde não existia previamente um território rural de identidade - viabilizando sua participação no Programa Territórios da Cidadania do Governo Federal.

Dado o número reduzido de territórios da cidadania que foram criados no Rio Grande do Sul, a necessidade de formular rapidamente uma proposta politicamente forte para apresentar ao Conselho Estadual do Programa parece ter sido uma condicionante importante para a configuração assumida pelo Território da Cidadania do Noroeste Colonial. Além disso, provavelmente teria sido impossível obter um território da cidadania para a "região de Ijuí" e outro para a "região Celeiro". Ao juntar as duas sub-regiões, a proposta de território perdeu em "identidade social", mas ganhou em poder de barganha político, pois conseguiu, desta forma, incluir vários segmentos do público prioritário do MDA, tais como agricultores familiares, indígenas, ribeirinhos e pescadores artesanais e assentados de reforma agrária, que se localizam em uma ou outra das regiões (em alguns casos em ambas). 
No caso deste Território, a institucionalidade criada segue o modelo padrão adotado, que consta de um órgão máximo, o Codeter, assessorado por um núcleo técnico e por grupos setoriais ou temáticos, com o objetivo de apoiar as reflexões sobre a elaboração e a avaliação de projetos territoriais, especialmente em uma circunstância na qual há um excesso de demanda por projetos diante da oferta disponível de recursos para financiá-los. A estrutura institucional é complementada pelo cargo de articulador territorial ligado a uma das organizações que fazem parte do Codeter.

Assim como no Território da Borborema, no Território do Noroeste Colonial a composição do Codeter está dividida entre as esferas do Estado e da sociedade civil, que predominam completamente. Na representação do Estado estão presentes agências federais, estaduais e municipais (Incra, Emater, bancos públicos, Companhia Nacional de Abastecimento - Conab, Fundação Nacional do Índio - Funai etc.); associações municipais das regiões Ijuí e Celeiros (Amuplan e Amuceleiro), que congregam prefeitos das duas regiões; universidades e outras organizações ligadas ao setor público. Entre os membros da sociedade civil incluem-se movimentos sociais (sindicais, de sem terra, dos pequenos produtores da agricultura, de povos indígenas, de mulheres etc.), além de cooperativas e associações de pequenos produtores, entre outros.

Existem ainda, como membros do Codeter, o que chamamos de instituições híbridas, compostas por representantes do Estado e da sociedade civil, e que no Noroeste Colonial são, principalmente, os Conselhos de Segurança Alimentar e Nutricional (Conseas) municipais.

Quando contrastamos a composição do Codeter e do Corede original (de 2003), as principais diferenças estão ligadas ao fato de que no Corede observa-se: 1) a maior importância da participação de instituições de ensino, em especial da Unijuí; 2) a existência de membros natos no Conselho; 3 ) a não obrigatoriedade da paridade entre poder público e sociedade civil; e 4) a relevância que as duas associações de municípios da região, a Amuceleiro e a Amuplan, fundamentalmente dominadas pelos prefeitos, têm na composição dos membros do Corede. Note-se, ademais, que, à diferença do que ocorre no Codeter, há também no Corede presença de representantes de deputados federais e estaduais com domicílio eleitoral na região e dos partidos políticos com peso regional e uma expressiva participação de instituições híbridas, princi- 
palmente de conselhos municipais setoriais, que congregam tanto membros do poder público como da sociedade civil.

A pesquisa de campo realizada no Território deixou clara uma cisão, por assim dizer, na avaliação que diferentes atores fazem da atuação e das expectativas em relação ao Corede e ao Codeter. Algumas entrevistas realizadas com representantes do poder público e de instituições privadas (aí incluída, por simplicidade, a Unijuí), embora reafirmem as limitações do Corede original para liderar estratégias regionais e formular projetos estratégicos para a região e ser controlado por interesses ligados principalmente à região de Ijuí, tendem a destacar sua contribuição na busca de uma institucionalidade intermediária (aos governos estadual e municipais) capaz de sobrepor-se aos meros interesses municipais fragmentados. Ademais, segundo eles, o Corede abriga um público mais amplo de grupos econômicos, sociais e políticos e trata também de forma mais abrangente as temáticas regionais (daí o papel de destaque desempenhado pelas universidades dentro dele). Esses atores conhecem muito pouco o Território da Cidadania recém-criado e destacam que, enquanto o Corede se enquadra nos moldes da democracia representativa, o Codeter faria parte de um processo de democracia participativa, com sua ênfase num público muito específico e na participação de pessoas e de movimentos sociais em detrimento das instituições oficiais.

Por outro lado, apesar das disputas existentes, é igualmente claro que o Território da Cidadania é visto pelos representantes da sociedade civil como uma conquista sua. As principais lideranças do Codeter não fazem parte do Corede, são outras pessoas, representantes de movimentos sociais, de pequenas cooperativas de agricultores familiares e de algumas agências estatais (como a Emater), por meio de técnicos com capacidade de diálogo com os movimentos sociais. Em geral fazem parte de um público com mais contato com as políticas do MDAassentados, agricultores familiares, indígenas, ribeirinhos - e que não se sentia representado no Corede. Talvez seja possível dizer, mesmo correndo o risco de sermos mal interpretados por ambos, que houve, por um lado, uma tentativa das organizações mais ativas da sociedade civil de neutralizar a participação de prefeitos e de universidades na construção do Codeter e, por outro, prefeitos e universidades também não se interessaram pela criação do Território da Cidadania, pouco participando nas discussões para a construção da proposta. 
Além disso, a relação do Território da Cidadania com os Coredes é muito fraca, as informações obtidas sugerem a existência de uma oposição inicial à sua criação pelo Corede Noroeste Colonial (região de Ijuí) e uma posição mais favorável por parte do Corede Celeiro. Tudo indica que as organizações da sociedade civil que lideraram a criação do Território e do Codeter não tiveram interesse em fazer com que o Corede e suas principais lideranças tomassem parte neste processo.

Numa breve síntese da estrutura do Codeter Noroeste Colonial, especialmente quando comparada com a estrutura do Corede preexistente, cabe sublinhar as seguintes características, em particular: 1) a criação de um território da cidadania numa região onde não existia previamente território rural de identidade; 2 ) a rapidez com que a proposta de território teve de ser concebida, de modo que, entre outros aspectos, a criação do Codeter foi acompanhada pela quase simultânea definição e aprovação de projetos territoriais, tendo em vista viabilizar seu financiamento através dos recursos inicialmente disponibilizados pelo programa federal;3) o envolvimento das organizações da sociedade civil na criação e na implementação do Colegiado; e 4) a composição paritária do Codeter em relação às representações do Estado e da sociedade civil, o que é uma exigência do Programa Territórios da Cidadania do Governo Federal.

Sem desmerecer o experimento representado pelo Corede, suas características são diversas das do Codeter, além de se tratar de uma institucionalidade criada pelo governo estadual, condicionada pela dinâmica política dos governos estaduais, e que não se enquadra rigorosamente na atual abordagem territorial. Os atores do Território Noroeste Colonial têm de lidar com políticas federais - do MDA e do Programa Territórios da Cidadania - sem uma experiência prévia com essas políticas no âmbito territorial. Ademais, como os atores principais que puxam a dinâmica do Codeter não têm uma participação relevante nos Coredes, pouco lhes serviu essa experiência como aprendizagem para uma convivência que, apesar de competitiva e conflitiva, tem de ser capaz de viabilizar comportamentos e decisões que tendam a servir a interesses comuns e não simplesmente a objetivos particulares.

A experiência dos territórios rurais de identidade, iniciada em 2003, tem propiciado, apesar de suas inúmeras dificuldades, uma vivência indispensável para os atores territoriais, obrigando-os a refletir sobre estratégias territoriais, a conviver com as diferenças existentes tanto 
no interior da sociedade civil quanto na relação com o Estado e a esforçar-se para transformar os colegiados territoriais em instituições relevantes para a tomada de decisões estratégicas acerca do futuro do território e não apenas para atender os interesses fragmentados dos diferentes atores que deles fazem parte, como é muito comum.

No caso do Noroeste Colonial, a falta desse aprendizado prévio acirrou os conflitos e as desconfianças já existentes entre os movimentos da sociedade civil e estimulou cada um a buscar atender seus interesses específicos e a dar continuidade ao trabalho que já vinha realizando anteriormente, a fazer alianças basicamente com esses objetivos, sem grande preocupação com a formulação de projetos estratégicos e de caráter efetivamente territorial. Na ausência desse aprendizado, a característica de programa governamental mais tradicional, de "cima para baixo", que o Programa Territórios da Cidadania ainda não conseguiu superar, aguçou uma "caça" por recursos governamentais a serem apropriados pelas diferentes organizações e movimentos, cada uma tentando garantir seu quinhão empregando seu poder de barganha político para tal.

O Território da Cidadania do Baixo Amazonas/PA está situado na região do Baixo Amazonas/PA que tem tradição como unidade político-administrativa de planejamento e de intervenção dos governos estadual e federal, em diferentes contextos políticos. Mais recentemente foi escolhida como Território Rural de Identidade no programa de mesmo nome da SDT/MDA e posteriormente foi transformada em Território da Cidadania.

No Baixo Amazonas (BAM) a mobilização social é antiga. Foi iniciada nos anos 1970 por meio da organização sindical associada à Fetag (Federação dos Trabalhadores da Agricultura) do Pará, com apoio dos movimentos eclesiais de base. Nos anos 1980 ganhou fôlego com a criação de projetos para a região que visavam fortalecer a agricultura familiar local. Na época foram discutidos temas como agroecologia, sistemas agroflorestais, processamento e comercialização direta de alimentos, sendo que grande parte dessas discussões foi desenvolvida com apoio de organizações não governamentais que atuavam no entorno, muitas delas de natureza ambientalista. O novo contexto dos anos 1990, em que passaram a coexistir antagonicamente um projeto neoliberal para a economia e a sociedade brasileira e um projeto democratizante voltado ao alargamento do conceito de público e à democratiza- 
ção dos espaços públicos, obrigou governo e sociedade civil a debaterem prioridades para a região, o que contribuiu para que os movimentos sociais existentes se fortalecessem e novos movimentos e organizações fossem criados.

De maneira sintética e utilizando as observações contidas no relatório do Projeto Diálogos (CIRAD/IPAM, 2009:12-14), é indispensável destacar que uma das características distintivas da região do Baixo Amazonas/PA é a coexistência (conflituosa) de diferentes projetos de desenvolvimento, que são defendidos por atores econômicos, sociais e políticos distintos e que representam basicamente os grupos formados por: a) empresas mineradoras, madeireiros e grandes produtores de grãos (os sojeiros); b) ribeirinhos, pescadores e outras comunidades tradicionais e suas organizações, como indígenas e quilombolas; c) pequenos produtores rurais e agricultores familiares; e d) setores ambientalistas e conservacionistas.

Um dos projetos de desenvolvimento é o das empresas de mineração, de madeireiros e de sojeiros que objetivam explorar os recursos naturais para exportação direta ou através de seu beneficiamento industrial. Sua relação principal é com as empresas internacionais e nacionais do agronegócio, com as agências governamentais e com os políticos regionais e nacionais. Defendem uma concepção de desenvolvimento que privilegia a criação de infraestrutura, principalmente de redes de comunicação (estradas, ferrovias) e portos. De forma simplificada, o desenvolvimento ocorre, segundo eles, através de uma sequência de encadeamentos que se inicia com a apropriação privada das terras e sua exploração comercial, e que gera uma correspondente necessidade de um leque amplo e variado de serviços, cuja oferta, por sua vez, gera empregos, principalmente nas cidades.

Outro projeto é o das comunidades ribeirinhas, dos indígenas, quilombolas e dos pescadores da várzea, cuja relação com os recursos naturais é muito particular, na medida em que seu modo de vida depende categoricamente desta relação, o que torna a preservação do meio ambiente uma variável crucial em sua equação de reprodução social. Em contextos em que os processos de modernização são intensos, como os que a região do BAM/PA está vivenciando, os projetos destes grupos de garantir a sustentabilidade de seus sistemas de produção e de preservar seus modos de vida tradicionais, mesmo que reelaborados pelas novas gerações, confrontam-se com as necessidades criadas pelo aces- 
so à modernização, tanto em termos de serviços, como de aumento de renda monetária, o que tende a pressionar o uso dos recursos naturais.

Um terceiro projeto de desenvolvimento é o dos agricultores familiares que procuram, premidos pela inserção nos mercados, pela necessidade de redução de custos monetários e pela grilagem de terras, uma forma de associar a produção agrícola e pecuária ao uso sustentável dos recursos que, simultaneamente, permita sua reprodução social ao longo do tempo e proporcione melhorias nas condições de vida de suas famílias. Também no caso deste projeto, a relação com o agronegócio e com o Estado é definidora de sua possibilidade de se constituir como uma proposta viável e alternativa ao modelo de modernização predominante defendido pelo agronegócio e amparado pelas principais agências governamentais.

O quarto projeto de desenvolvimento é o dos setores ambientalistas e conservacionistas que propõem ações voltadas para a conservação e o manejo sustentável dos recursos naturais, do ambiente e das paisagens e para a preservação dos povos e das culturas tradicionais locais. De acordo com este projeto, se o processo de conservação e de preservação de recursos, de tradições e de modos de vida for razoavelmente bem sucedido, abrem-se condições naturais favoráveis ao desenvolvimento do ecoturismo e do turismo rural, como atividades geradoras de emprego e renda para as populações e mesmo para os empreendimentos comerciais locais.

Como é fácil perceber, os quatro projetos comportam conflitos mais ou menos intensos entre os atores do Território, pois as propostas que defendem afetam desigualmente as condições do meio ambiente e os grupos sociais existentes, tanto em termos de quem arca com os custos, como de quem se apropria dos benefícios de sua implementação.

Além disso, os projetos também estão associados a uma dimensão de futuro para a região do BAM/PA e mesmo para toda a região amazônica. A disputa pela implementação dos diferentes projetos é intensa, embora nenhum deles possa ser ainda considerado "vencedor" e portador do futuro da região. Entretanto, é indiscutível a ocorrência de alguns processos - como construção de grandes obras de infraestrutura, expansão da pecuarização e da lavoura de exportação etc - que podem restringir ou comprometer as possibilidades futuras de alguns desses projetos, principalmente em relação à conservação e/ou exploração da floresta amazônica. Note-se, em contraposição, que são perceptíveis as 
possibilidades de convergência entre os três últimos projetos, de modo que é provável que possam ser construídas alianças políticas entre seus principais protagonistas em torno de um projeto comum, mais robusto politicamente e com maior capacidade de disputa em relação às proposições oriundas das empresas nacionais e internacionais de mineração e do agronegócio, dos pecuaristas e dos sojeiros.

A institucionalidade criada para o Território do Baixo Amazonas/PA não é distinta da dos dois outros territórios de que estamos tratando. $\mathrm{O}$ órgão máximo desta institucionalidade é o Codeter, concebido como uma instituição de articulação, cooperação e deliberação, por parte dos diferentes atores que o compõem, de ações territoriais que garantam o desenvolvimento sustentável do Baixo Amazonas/PA. É composto de uma plenária, de um núcleo diretivo e de um núcleo técnico, além da função de articulação territorial.

Como acontece nos outros dois territórios, os membros do Codeter são oriundos basicamente do Estado e da sociedade civil. Nesta última sobressai a atuação da Federação dos Trabalhadores da Agricultura do Estado do Pará (Fetagri), dos sindicatos de trabalhadores rurais a ela ligados, do Sindicato dos Trabalhadores na Agricultura Familiar (Sintraf) de Santarém vinculado à Federação dos Trabalhadores na Agricultura Familiar (Fetraf) Brasil, do Centro de Estudos, Pesquisa e Formação dos Trabalhadores do Baixo Amazonas/PA (CEFT-BAM), onde está localizada a função de articulação territorial, e do Instituto de Pesquisa Ambiental da Amazônia (Ipam), além de outros movimentos sociais (pescadores, quilombolas, indígenas e mulheres), associações e cooperativas e ONGs. Entre os membros do Estado destacam-se a Unidade Regional do BAM da Secretaria de Agricultura do Governo Estadual (Sagri) e a Emater, além de outras agências e bancos do governo federal (Embrapa, Instituto Brasileiro de Meio Ambiente - Ibama, Incra, Caixa Econômica Federal, Banco do Brasil, Banco da Amazônia etc), universidades, prefeituras, câmaras e secretarias de agricultura municipais. Embora tenham acento no Colegiado, nem todas as prefeituras participam ativamente do mesmo. Repete-se aqui a tendência de resistência à participação na institucionalidade territorial por parte da maioria dos prefeitos, como ocorre, aliás, nos outros territórios investigados.

Aparentemente, o Codeter do BAM/PA possui uma especificidade em relação aos demais pelo fato de que entre seus membros existe uma or- 
ganização representativa do setor empresarial regional que é o Sindicato Rural de Santarém (Sirsan), organização dos grandes produtores rurais e criadores de gado do município. Sua presença efetiva tem sido praticamente nula até agora, mas, segundo o articulador territorial, há indícios do interesse em fazer parte do Codeter oriundos não apenas da associação comercial e de organizações coletivas de pecuaristas, mas também de empresas privadas, como mineradoras (de bauxita, por exemplo) e a própria Cargill, que possui um terminal no porto de Santarém. Esta é uma situação bastante controversa, mas, se for concretizada, o Codeter BAM vai passar a contar com membros não apenas representantes do governo e da sociedade civil, como é a prática nos territórios existentes no país, mas também do mercado, o que pode significar uma experiência única no campo dos territórios da cidadania no país. Caso se concretize, este será um notável desafio para o Colegiado, que refletirá, também, um aparente reconhecimento da importância do Programa Territórios da Cidadania pelo setor privado regional, bem como a disposição de, pelo menos, segmentos da sociedade civil local de "sentar" com representantes do setor privado no Codeter, numa tentativa de legitimar e fortalecer o mesmo, buscando relativizar a prática generalizada das grandes empresas e associações do setor empresarial de "falar direta e exclusivamente com o governo e com os políticos".

\section{Atores e Protagonismo Social nos Territórios Investigados}

Quando consideramos a dinâmica territorial da perspectiva da participação dos atores e do protagonismo social, as experiências dos três territórios investigados mostram trajetórias muito diversas, cuja comparação é bastante interessante e rica tanto do ponto de vista metodológico, quanto da complexidade histórica, política, econômica, social e cultural da realidade dos territórios criados no Brasil por meio de programas do governo federal ${ }^{12}$.

No caso do Território da Cidadania da Borborema/PB, as particularidades da dinâmica e do protagonismo social territorial estão profundamente relacionadas com as experiências sociais e institucionais ocorridas na região da Borborema, a partir da década de 1990, por três razões principais.

Primeiro, porque a renovação do sindicalismo dos trabalhadores rurais, que começou a se consolidar na região por volta do início dos anos 
1990, a partir dos municípios de Lagoa Seca, Remígio e Solânea, e que levou à criação do Polo Sindical da Borborema em 1998, consolidou progressivamente a perspectiva política de atuar coletivamente, em rede, numa escala regional - superando o isolamento representado pela ação restrita ao âmbito municipal - articulando sindicatos de diversos municípios das regiões da Borborema e do Cariri, com diferentes ambientes agroecológicos. Essa estratégia de atuar coletivamente, em rede, numa escala regional representou um acúmulo de aprendizado e de experiência para o movimento sindical e para as representações dos agricultores familiares participantes do Polo Sindical que os colocou numa posição diferenciada para participar e influenciar na dinâmica institucional, uma vez deslanchada a política territorial da SDT.

Segundo, porque a experiência do agreste paraibano representou a oportunidade de articulação do movimento sindical com organizações não governamentais, especialmente a AS-PTA, voltadas para a construção de propostas metodológicas, de formação e de intervenção na realidade local tendo em vista a busca de modelos alternativos de desenvolvimento rural, baseados no reconhecimento da força e da diversidade produtiva e cultural da agricultura familiar, na valorização do conhecimento e da capacidade de inovação desses agricultores, e na sustentabilidade ambiental, econômica, cultural e social da atividade agrícola e do desenvolvimento rural.

Essa articulação/parceria iniciou-se em 1993 nos municípios de Lagoa Seca, Remígio e Solânea e foi progressivamente amadurecendo o intento de ampliar a escala dos processos sociais e das redes de inovação para toda a região do agreste da Paraíba. Para tanto, mostrou-se indispensável a existência de um ator regional com capacidade para coordenar política e metodologicamente o processo de ampliação, garantindo, ao mesmo tempo, que fosse assumido como um projeto dos agricultores familiares regionais. Esse ator passou a ser o Polo Sindical da Borborema e seu objetivo é a construção de um projeto comum de desenvolvimento local baseado na agroecologia.

A realização do I Seminário da Agricultura Familiar do Compartimento da Borborema, em 2001, lançou as bases desse projeto, que passou a ser conhecido também como Projeto de Transição Agroecológica ou de Agricultura Familiar Agroecológica. O ponto que merece destaque adicional neste contexto é que a capacidade de manter, amadurecer e consolidar essa articulação entre movimento sindical e organizações 
não governamentais do tipo da AS-PTA, demonstrada pela experiência do agreste paraibano, além de permitir a construção de uma identidade agroecológica comum entre importantes segmentos da agricultura familiar, tornou o Polo Sindical da Borborema portador privilegiado de um projeto de desenvolvimento rural local sustentável bastante legitimado em diversos segmentos da sociedade e da economia locais, o que reforçou a sua importância estratégica na institucionalidade e na dinâmica econômica e social do novo Território da Borborema.

Terceiro, porque a determinação do movimento sindical de atuar regionalmente e de formular e implementar um projeto concreto de desenvolvimento rural alternativo e sustentável para a região da Borborema e do Cariri esteve desde o início inseparavelmente associada à decisão de influenciar de forma mais permanente as políticas públicas, existentes ou a serem criadas, para a agricultura familiar do semiárido paraibano, ou seja, de não abrir mão do reconhecimento da importância decisiva da parceria com o Estado, e de que essa parceria deveria se efetivar através do desenho e da execução de políticas públicas diferenciadas para a agricultura familiar regional.

Na concepção do movimento sindical não bastava atuar regionalmente, nem era suficiente esboçar um projeto de desenvolvimento rural sustentável para o semiárido estadual. Era fundamental, além disso, articular-se com as políticas públicas existentes e influenciar e participar na formulação e na execução de novas políticas públicas, sem o que seria impossível amadurecer e legitimar a proposta política do Polo Sindical e avançar com experiências concretas e abrangentes de projetos estratégicos que viabilizassem a implementação progressiva do projeto de transição agroecológica. Uma ideia central era: "não se pode abrir mão da presença do Estado".

Em nossa avaliação, os três elementos acima assinalados dão uma qualidade diferenciada aos movimentos sociais da região e atribuem-lhes capacidade de iniciativa e de protagonismo indispensável para a implementação da abordagem territorial, tanto do ponto de vista da democratização da governança territorial, quanto da formulação de projetos estratégicos de desenvolvimento rural sustentável.

Como consequência, no Território da Cidadania da Borborema, o protagonismo social territorial foi conduzido por organizações da sociedade civil, especialmente pelo movimento sindical, associado à proposta ou projeto de transição agroecológica ou de agricultura familiar 
agroecológica, entendido como referência norteadora das ações e concepções relativas ao desenvolvimento rural no território, inclusive, e muito significativamente, para orientar o Codeter na escolha dos projetos territoriais a serem financiados com recursos da SDT/MDA e considerados como projetos estratégicos para o desenvolvimento rural.

Por outro lado, no caso da Borborema, a abordagem territorial tem enfrentado oposição nos governos municipais e estadual, o que tem dificultado sobremaneira a concretização dos projetos estratégicos aprovados pelo Codeter, dada a inexistência de um marco jurídico para o território. Esta situação coloca desafios para o desenvolvimento territorial que dificilmente serão enfrentados sem a participação mais ativa do governo federal e do MDA. Nesta perspectiva, é interessante considerar o Programa Territórios da Cidadania de uma outra ótica: como o mesmo pode contribuir para fortalecer o protagonismo social territorial, corrigir os equívocos e omissões resultantes deste processo, especialmente relacionados com os atores estatais, e enfrentar os obstáculos concretos existentes para a consolidação da abordagem e da institucionalidade territoriais? Poder responder de alguma forma a essas questões, ou a parte delas, pressupõe a necessidade urgente de avançar no enraizamento do programa nos atores e na institucionalidade territoriais.

O Território da Cidadania Noroeste Colonial do RS foi criado, como vimos, em uma região onde preexistia uma institucionalidade de governança regional ligada ao governo estadual, a dos coredes. Na verdade, a criação do território foi uma iniciativa de organizações da sociedade civil que se sentiam marginalizadas pelo Corede e que juntaram forças para tentar participar do Programa Territórios da Cidadania no Rio Grande do Sul. De modo a conseguir sua incorporação foi necessário atender aos requisitos do programa, entre os quais está a presença significativa do público prioritário atendido pelas políticas do MDA (agricultores familiares, indígenas, ribeirinhos, quilombolas etc). Para tanto, o Território da Cidadania Noroeste Colonial praticamente recriou o antigo Corede Noroeste Colonial (acrescido do município de Cruz Alta), que havia sido desmembrado posteriormente porque não conseguia dar conta das importantes diferenças socioeconômicas que existem entre as duas sub-regiões norte (Celeiro) e sul (Noroeste Colonial) artificialmente incluídas no Corede Noroeste Colonial original e no novo Território da Cidadania. 
Com este problema de origem, que unificou em um dois territórios com características socioeconômicas diversas e com presença diferenciada de atores sociais, e sem qualquer experiência prévia de aprendizado da abordagem territorial - ao contrário de outros territórios da cidadania que foram previamente territórios rurais de identidade - nossa pesquisa verificou o que podemos chamar de ausência de protagonismo social no território, pela inexistência de atores que liderem hegemonicamente a implantação da institucionalidade territorial e que estejam aptos a construir uma proposta de desenvolvimento rural para a região capaz de atrair a composição de uma base social e política significativa de apoio a esta proposta.

O que observamos foi uma enorme fragmentação das organizações da sociedade civil local, com visões e propostas muito diversas sobre o diagnóstico, os problemas e as soluções para o território (ou para os dois territórios diferentes que existem na região), e com enorme desconfiança umas das outras. Algo muito distante do que podemos chamar de uma coalizão de atores com capacidade de liderar a implementação da institucionalidade e da política territoriais. Como consequência, apesar da dedicação e da boa vontade de muitas pessoas envolvidas no processo, a ação coletiva das organizações e movimentos sociais assemelha-se muito ao modelo de "caça às rendas" (rent seeking), no qual cada uma das sub-regiões e cada uma das organizações ou movimentos tenta garantir a sua parte nos recursos financeiros à disposição do Codeter, na justificativa de que o projeto que apresenta é "estratégico" porque reflete o seu diagnóstico sobre a realidade territorial, que é o único "correto".

O resultado é o acirramento dos conflitos e divergências existentes entre essas organizações, enfraquecendo a possibilidade de construção tanto da legitimidade política do novo arranjo institucional do território como de uma estratégia conjunta que viabilize enfrentar, a partir dos diferentes recursos disponibilizados pelo programa, os desafios do combate à pobreza e às desigualdades regionais e da melhoria das condições econômicas e sociais dos agricultores familiares e das populações tradicionais aí residentes.

Esta situação de inexistência de protagonismo social no território agrava-se ainda mais porque o governo estadual existente em 2009 era hostil à abordagem territorial e os governos municipais, de modo geral, ou são contrários ou indiferentes ou cautelosos em relação à questão terri- 
torial, especialmente em um ambiente de fragmentação e de conflito entre as organizações e movimentos da sociedade civil. Além disso, os prefeitos locais expressam uma sensação de perplexidade e de fragilidade frente à "decadência" ambiental e econômica do meio rural, especialmente na região Celeiro. Neste contexto, é preciso reavaliar a atuação do governo federal e do MDA, que não pode fugir à necessidade de formular uma política pró-ativa frente a esta questão crucial da construção de protagonismo social nos territórios, discutindo e definindo que papel pode e deve ocupar neste processo. A mesma observação se aplica, e talvez com ainda maior veemência, ao Programa Territórios da Cidadania.

No Território da Cidadania do Baixo Amazonas/PA foi possível verificar que os movimentos sociais, em especial o movimento sindical, tiveram historicamente um papel muito importante na difusão da ideia de território. Da mesma forma que na Borborema, também aqui o movimento sindical "não deu as costas para o Estado", pelo menos a partir de certo momento, em seu reconhecimento da relevância das agências estatais e das políticas públicas, como atesta, por exemplo, a reconhecida importância que teve a Fetagri para impedir a extinção da Emater/PA no auge dos tempos neoliberais.

Com a eleição de uma governadora do Partido dos Trabalhadores (PT), Ana Julia Carepa, muitos militantes de movimentos e organizações sociais foram chamados a participar do governo estadual. Este foi o caso da unidade regional da Sagri. A observação do Codeter e as entrevistas com diferentes atores sociais locais deixaram claro que a unidade regional da Sagri é o ator que lidera o protagonismo social no território do BAM/PA.

Este protagonismo é possível porque a Secretaria assumiu a abordagem territorial como um instrumento fundamental de sua ação política e ganhou legitimidade frente ao Codeter e aos atores que o compõem, pois (1) desempenha um papel central para a garantia de viabilização dos projetos territoriais, por sua condição de ente federativo, que lhe permite contornar o obstáculo da ausência de um marco jurídico territorial e (2) é portadora de uma proposta de desenvolvimento rural para o território, voltada para os agricultores familiares e para as populações tradicionais, baseada na abordagem dos arranjos produtivos locais (APLs), que se transformou na linguagem comum utilizada por todos os atores sociais (governamentais e da sociedade civil) do Codeter e que tem viabilizado a comunicação, o diálogo e a articulação des- 
ses diferentes atores em torno da proposta de desenvolvimento rural baseada nos APLs. Ademais, essa proposta tem sido progressivamente utilizada para orientar, pelo menos em parte, a escolha de projetos (estratégicos) pelo Codeter, a partir dos recursos federais disponíveis.

Como nos outros dois territórios analisados, também no caso do BAM/PA o poder público municipal não é muito simpático à política territorial, embora o envolvimento dos prefeitos tenha, de modo geral, aumentado nos territórios com a criação do Programa Territórios da Cidadania. No entanto, também neste aspecto o protagonismo da Sagri tem se manifestado pela tentativa de formulação de uma estratégia - que já está sendo experimentada - segundo a qual os municípios são incorporados à política territorial não apenas por meio da participação das prefeituras, mas também pela reativação dos Conselhos Municipais de Desenvolvimento Rural, que passam a ser peças-chave e interconectadas da institucionalidade territorial não simplesmente porque seus representantes têm assento no Codeter mas porque os projetos municipais para serem enviados ao Codeter devem ser aprovados primeiro pelos conselhos municipais.

Um desafio adicional que o protagonismo social territorial vai ter de enfrentar no caso do Território da Cidadania do BAM/PAé de como fazer frente à existência, mencionada anteriormente, de outros projetos de desenvolvimento para a região ligados às grandes empresas multinacionais e do agronegócio, que se chocam frontalmente com a proposta de desenvolvimento rural baseado na agricultura familiar e nas populações tradicionais (ancorada na abordagem dos APLs), e de como se posicionar diante de outras medidas de política do governo federal como, por exemplo, a construção de grandes obras de infraestrutura (barragens hidrelétricas) que vão impactar significativamente o meio ambiente e a socioeconomia da região do BAM e afetar as possibilidades e os rumos da proposta do Codeter. Em nossas entrevistas ouvimos muito pouco acerca dessas iniciativas por parte dos atores do Codeter, o que é preocupante se significar o seu desconhecimento e refletir um certo isolamento do Colegiado em relação a movimentos econômicos e políticos mais amplos.

\section{CONSIDERAÇÕES FINAIS}

A política de desenvolvimento territorial no meio rural representou um avanço considerável, isto é, uma inovação institucional, ao implementar um formato mais adequado à ampliação da capacidade de par- 
ticipação social dos atores no processo de diálogo, negociação, desenho e planejamento de políticas públicas, incrementando aquilo que poderíamos denominar como um dos atributos da capacidade governativa e da gestão social dos processos de desenvolvimento. É certo que esse acúmulo apresentou-se de forma completamente desigual nas diversas experiências existentes, tanto no que tange ao seu grau de cobertura (a capacidade de inclusão dos mais diferentes atores locais), como no que se refere ao seu grau organizacional (a forma pela qual se deu a constituição efetiva dos espaços e procedimentos utilizados nas diferentes etapas do ciclo da gestão social) e ao seu grau de efetividade social (a representatividade e o alcance dos resultados alcançados com as ações operadas pela política - tanto em relação aos instrumentos adotados como em relação à forma como os mesmos foram empregados).

Pareceu-nos que a diversidade das situações e das soluções encontradas em cada caso, malgrado a existência de procedimentos normativos padronizados, revelou-se um instrumento rico de canalização da energia social acumulada, construída e/ou reconvertida, em prol de projetos que, de uma maneira ou de outra, obtiveram algum estatuto territorial, buscando ultrapassar os limites dos interesses circunscritos a grupos específicos e/ ou a determinados municípios. Essa autonomia relativa dos atores presentes no território permitiu a emergência de proposições as mais diversas, moldando e readaptando a normatividade excessiva das ferramentas administrativas desenhadas para o programa.

A criação dos territórios colaborou para estabelecer as condições necessárias à instauração de um diálogo constante entre diferentes atores sociais locais que até então tradicionalmente não "se falavam". Esse processo contribuiu para que os conflitos existentes entre os distintos atores que constituem o território fossem melhor explicitados e "trabalhados", estimulando-os a implementarem ações conjuntas, em diálogo ou não com o Estado, orientadas para o desenvolvimento. Essa experiência permitiu, em diferentes circunstâncias, construir e legitimar uma nova institucionalidade operacional que intenta viabilizar a discussão, comparação e seleção de projetos concretos e coletivos de desenvolvimento local, ultrapassando os interesses eleitorais ou oportunistas de algumas prefeituras.

Contudo, são diversos os desafios que a política de desenvolvimento territorial enfrenta no Brasil. Ainda que algumas experiências do Pro- 
nat tenham sido bem sucedidas, e outras do Programa Territórios da Cidadania estejam em curso, são numerosos os casos em que os resultados têm sido modestos e reduzidos: em vários territórios os fóruns ou colegiados não se fazem representativos de todos os segmentos sociais da agricultura familiar local ou, ainda, os colegiados, em lugar de representarem espaços propícios à participação ampliada, figuram muito mais como estruturas impostas por determinadas políticas públicas para que os atores locais acessem recursos federais. Dessa forma, esses espaços não raro acabam excluindo de sua dinâmica os segmentos menos articulados e mais carentes, reproduzindo a mesma estrutura preexistente de poder local e privilegiando alguns segmentos em detrimento de outros. Ainda são recorrentes os casos em que a abordagem de "desenvolvimento" sugerida limita-se, em sua maioria, a projetos setoriais e produtivos, excluindo de sua formulação a articulação da agricultura familiar com outros importantes segmentos sociais.

Há, contudo, uma clara necessidade de melhorar a forma como o Estado atua nas instâncias territoriais, fortalecendo o processo de "profissionalização" da atividade de gerenciamento territorial, corroborando para uma burocracia mais robusta nessas instâncias. É preciso não confundir aumento de participação e controle social dos atores com desresponsabilização das funções que deveriam ser típicas de Estado (em particular, mobilizar os atores mais frágeis, dotar a escala territorial de infraestrutura e recursos necessários para seu funcionamento, dispor de funcionários com disponibilidade de tempo para o encaminhamento e execução das ações e dos projetos territoriais etc.). Isso fica evidente, por exemplo, no papel estratégico delegado aos articuladores territoriais. Por outro lado, um aumento da burocracia qualificada não exclui - e não deveria excluir - a efetiva participação dos atores no processo de tomada de decisão das ações territoriais.

Em quase todos os territórios existentes, a institucionalidade territorial não contempla a presença de atores representativos da esfera social do mercado. Em cada caso aparecem razões particulares para explicar essa situação, mas, de modo geral, os atores da sociedade civil têm dificuldade em aceitar a participação dos representantes do mercado, os quais, por sua vez, também não demonstram interesse em participar. Esta situação configura um enorme e importante desafio para a política territorial, o qual não se enfrenta simplesmente reafirmando a obviedade abstrata de que os atores do mercado têm de estar presentes 
nestas institucionalidades, sem examinar as situações concretas de cada território, sua história, a força política e os projetos de desenvolvimento de que são portadores seus diferentes atores sociais e as possibilidades de cooperação entre eles. Partimos da ideia de que a sustentabilidade do desenvolvimento territorial depende de uma adequada combinação das esferas do Estado, da sociedade civil e do mercado na institucionalidade e na dinâmica territoriais. Mas, seguindo Offe (2001), também acreditamos que as combinações possíveis de serem obtidas em cada caso concreto dependem de deliberações democráticas construídas processualmente são, como tal, questões de política e, portanto, passíveis de controvérsia e de contestação.

A instância primordial de articulação das políticas e do exercício da gestão social é o colegiado. Porém, como fortalecer o codeter? Primeiramente, pelo reconhecimento, por parte do governo, destas arenas como espaços de planejamento, execução e avaliação das políticas públicas. Segundo, garantindo o permanente funcionamento e capacitação dessas estruturas, o que confere maior legitimidade/qualidade aos codeters e às ações dos seus membros. Terceiro, estimulando a base social local a atuar nesses espaços. Na medida em que são arenas (razoavelmente) abertas, elas não se constituem num lócus de disputa dos diferentes segmentos e de projetos estratégicos que estão acostumados a operar em circuitos mais restritos e controlados. O desafio é tornar esses fóruns visíveis e legítimos diante dos projetos e ações que perpassam as esferas locais e regionais (Delgado et alii, 2008). E quarto, criando condições para que seus membros fortaleçam sua capacidade propositiva e de interação frente aos atores do mercado, reconhecendo que o território é também um mercado e que há implicações inevitáveis que derivam dessa constatação.

Neste artigo destacamos também a importância e as características particulares que assume o protagonismo social nos territórios, dependendo da história, da identidade social, das especificidades dos atores existentes nos mesmos, entre outros elementos empíricos relevantes para cada caso considerado. Não obstante, em nossa análise observamos que para a existência de protagonismo social é indispensável: (1) a presença de atores com capacidade de construção de coalizões ou de hegemonia que, embora defendendo interesses próprios, consigam a cooperação (ou a aliança) de outros atores, de modo a liderar a difusão coletiva da abordagem territorial e a implantação de sua institucionalidade; e (2) que esses atores sejam portadores de "ideias" e de propostas 
de desenvolvimento rural para o território que possam tanto "unificar", por assim dizer, a linguagem comum dos atores territoriais, facilitando a capacidade de comunicação e de cooperação entre eles, como orientar, progressivamente, a formulação e a aprovação de projetos estratégicos coerentes com essas propostas de desenvolvimento.

Como não há garantia de que um território possua atores com capacidade de viabilizar os requisitos necessários ao protagonismo social, esta é uma dimensão à qual os programas governamentais, em especial os territórios da cidadania, deveriam dedicar mais atenção, o que requer uma maior interação do programa com os atores e a institucionalidade territoriais.

Em suma, uma experiência com o calibre da política territorial existente no contexto brasileiro recente apresenta janelas de oportunidade para inovações institucionais e mecanismos de governança e gestão participativa que não devem ser desprezadas. $\mathrm{O}$ acúmulo observado até o momento confere à escala supramunicipal um espaço importante no desenho e implementação de políticas que, se por um lado não eliminam as iniciativas municipais, por outro revelam a capacidade que determinados projetos possuem em atingir uma esfera mais ampla, garantindo sua continuidade à medida que legitima suas ações no lastro de atores sociais envolvidos, dispondo de certa autonomia em relação aos humores da política local.

(Recebido em março de 2010)

(Reapresentado em agosto de 2011)

(Versão definitiva em setembro de 2011) 


\section{Nelson Giordano Delgado e Sergio Pereira Leite}

\section{NOTAS}

1. Para uma exposição detalhada dos resultados gerais da pesquisa e dos estudos de caso mencionados consultar Delgado et alii (2008), Delgado e Zimmemann (2008a, 2008b, 2009, 2010) e Leite et alii (2009).

2. Como é sabido o Pronat não é a única experiência de territorialização de políticas públicas no contexto brasileiro recente. Os trabalhos de Senra (2007) e Araújo (2007) abordam de forma bastante apropriada esse tema.

3. Segundo o primeiro parágrafo da referida Resolução: “I- por representatividade entende-se que a base das organizações sociais esteja representada por essas entidades; II - a diversidade é a representação dos diferentes atores sociais que atuam no processo de desenvolvimento rural sustentável, sejam jovens, mulheres, quilombolas, agricultores familiares ligados a diferentes comunidades e/ou arranjos produtivos, pequenos empreendedores etc.; III - a pluralidade pressupõe que as diferentes organizações (associações, sindicatos, cooperativas etc.) de uma mesma categoria estejam representadas, assim como todas as concepções de desenvolvimento rural sustentável".

4. Segundo documento da SDT, a gestão social é entendida como uma "certa maneira de gerir assuntos públicos, nesse caso em particular as políticas e iniciativas voltadas para a promoção do desenvolvimento das áreas rurais. Para que ela ocorra de maneira eficaz, deve se apoiar em sistemas descentralizados, baseados em forte participação, com maior fluidez e densidade de informação, de estabelecimento de parcerias e de articulações em rede. Em desenvolvimento territorial isso requer a construção de pactos de concertação social [...], o detalhamento do pacto em um plano de desenvolvimento negociado, a construção de institucionalidades que representem espaços de compartilhamento do poder e das responsabilidades e, finalmente, mecanismos de controle social sobre as ações previstas no plano" (Brasil, MDA/SDT, 2005b:11).

5. Preferimos utilizar a ideia de governança não como uma maneira de fazer um bom governo a partir da criação de um ambiente social e economicamente apropriado para tanto, como foi amplamente divulgado por agências multilaterais, mas sim nos aproximando da noção de capacidade governativa, defendida por Santos (1997:4), segundo o qual, em vez de ficar restrito a questões específicas associadas aos aspectos gerenciais administrativos do Estado, busca-se compreender o jogo de relações entre os diferentes atores operando num determinado contexto e os arranjos político-institucionais daí derivados.

6. Foram produzidos quatro relatórios na pesquisa sobre este assunto, Delgado e Zimmermann (2008a, 2008b, 2009 e 2010), organizados de forma a tratar dos cinco temas enumerados acima. Para a elaboração dos mesmos foram utilizados documentos, livros, ensaios, artigos, teses e dissertações acadêmicas relativos aos territórios e aos temas tratados, além de informações estatísticas. Este levantamento bibliográfico e estatístico completou as informações originais obtidas por meio de entrevistas com atores sociais relevantes realizadas pela equipe do OPPA/CPDA em pesquisa de campo. Foi possível concretizar, ao todo, entrevistas com cerca de 72 participantes da institucionalidade e da política territorial nos três territórios, incluindo articuladores (e ex-articuladores) territoriais, representantes de movimentos sociais (sindicais, de mulheres, sem terra, quilombolas, pescadores, indígenas etc), de ONGs, de sindicatos rurais patronais, do poder público municipal (prefeitos, secretários e técnicos), 
do poder público estadual (secretários e técnicos), de agências do governo federal, de agências e de bancos governamentais, de membros do colegiado territorial (e suas comissões) e de outros colegiados existentes, de comissões municipais de desenvolvimento rural, de representantes de associações de produtores rurais e de associações comerciais municipais, de dirigentes de cooperativas agrícolas, de empresas multinacionais e de dirigentes e pesquisadores de universidades regionais.

7. Isto não significa que a participação dos representantes do mercado está, em princípio, vedada nos espaços públicos de participação. As empresas privadas de modo geral não participam diretamente nesses espaços. Tendem a ser representadas por associações de empresários ou por outros tipos de associações que, como associações, fazem parte da esfera da sociedade civil. A questão da combinação da participação dos atores do Estado, do mercado e da sociedade civil na institucionalidade dos territórios pesquisados é um tema polêmico, sobre o qual voltaremos mais à frente.

8. Ver a respeito Dagnino (2002), Dagnino et alii (2006) e Avritzer (2002).

9. Certamente é possível dizer que o lugar que os atores da sociedade civil-que surgem e se consolidam no país de maneira autônoma a partir da década de 1970 - desempenharam na democratização brasileira deu-lhes a capacidade de reivindicar a criação e a participação nos espaços públicos mencionados acima e consagrados pela Constituição de 1988. Por outro lado, a importância central dos atores do mercado no projeto de modernização implementado pelo Estado autoritário acirrou a desconfiança e a oposição à sua participação nesses espaços.

10. Note-se que a demanda por esta substituição ganhou ampla legitimidade pública, em função das diferentes avaliações realizadas, por pesquisadores, técnicos e organizações sociais, das limitações da escala municipal para a realização de experiências sustentáveis de desenvolvimento rural. Outra discussão, menos consensual, diz respeito à forma e ao ritmo com que foi feita.

11. Existe uma razoável literatura sobre a experiência dos coredes. Chamamos atenção aqui para Bandeira (2007) e Veiga (2006).

12. Entendemos protagonismo social territorial como um processo através do qual determinados atores sociais existentes no território agem coletivamente como portadores da abordagem territorial e como impulsionadores principais da implementação tanto da institucionalidade como do desenvolvimento territorial. 


\section{Nelson Giordano Delgado e Sergio Pereira Leite}

\section{REFERÊNCIAS BIBLIOGRÁFICAS}

ARAÚJO, Tânia Bacelar de. (2007), Políticas Públicas e Promoção do Desenvolvimento em Bases Territoriais. Trabalho apresentado no II Fórum Internacional Desenvolvimento Territorial: Articulação de Políticas Públicas e Atores Sociais. Salvador, 6-9 de novembro.

AVRITZER, Leonardo. (2002), Democracy and the Public Space in Latin America. Princeton/Oxford, Princeton University Press.

BANDEIRA, Pedro Silveira. (2007), “Uma Experiência de Institucionalização de Regiões no Brasil: Os Coredes do Rio Grande do Sul”. Disponível em http:/ / www.cidts.ufsc. br/articles/ArtigoBandeira.pdf

BONNAL, Philippe e PIRAUX, Marc. (2007), Dinâmicas Territoriais, Projetos Coletivos e Multifuncionalidade da Agricultura Familiar na Região do Entorno de Campina Grande (Paraíba). Rio de Janeiro. (Relatório 3.4 - Pesquisa e ações de divulgação sobre o tema da multifuncionalidade da agricultura familiar e desenvolvimento territorial no Brasil).

BRANDÃO, Carlos. (2007), “Territórios com Classes Sociais, Conflitos, Decisão e Poder", in A. C. Ortega e N. Almeida Filho (orgs.), Desenvolvimento Territorial: Segurança Alimentar e Economia Solidária. Campinas, Alínea.

BRASIL. MINISTÉRIO DO DESENVOLVIMENTO AGRÁRIO/CONSELHO NACIONAL DE DESENVOLVIMENTO RURAL SUSTENTÁVEL (CONDRAF). (2005), “Resolução no 52", de 16 de fevereiro de 2005. Diário Oficial da União, 17/2/2005.

(2005a), Institucionalidades para a Gestão Social do Desenvolvimento Rural Sustentável. Brasília, MDA/Condraf (Série Documento do Condraf, 1).

(2004), "Resolução o 48", de 16 de setembro de 2004. Diário Oficial da União, $23 / 9 / 2004$.

BRASIL. MINISTÉRIO DO DESENVOLVIMENTO AGRÁRIO/SECRETARIA DE DESENVOLVIMENTO TERRITORIAL (SDT). (2007), Territórios da Cidadania: Proposta do Ministério do Desenvolvimento Agrário para Redução da Desigualdade Social no Meio Rural Brasileiro. Brasília, MDA/SDT.

. (2006a), Referências para a Gestão Social dos Territórios Rurais: Guia para a Organização Social. Brasília, MDA/SDT (Documentos de Apoio, 3).

. (2006b), Referências para a Gestão Social dos Territórios Rurais: Guia para o Controle Social. Brasília, MDA/SDT (Documentos de Apoio, 4).

. (2005a), Plano Territorial de Desenvolvimento Rural Sustentável: Guia para o Planejamento. Brasília, MDA/SDT (Documentos de Apoio, 2).

(2005b), Referências para a Gestão Social de Territórios Rurais. Brasília, MDA/SDT (Documentos Institucionais, 3).

. (2005c), Marco Referencial para Apoio ao Desenvolvimento de Territórios Rurais. Brasília, MDA/SDT (Documentos Institucionais, 2).

. (2005d), Referências para uma Estratégia de Desenvolvimento Rural Sustentável no Brasil. Brasília, MDA/SDT (Documentos Institucionais, 1). 
CIRAD/IPAM. (2009), Espaços e Instrumentos de Desenvolvimento Territorial no Território Baixo Amazonas/PA. Relatório de missão - 8 a 21 de fevereiro (Documento Interno).

COUTO, Vitor e ROCHA, Alynson dos S. (2006), Reveses à Questão Territorial na Região de Irecê, Bahia. Trabalho apresentado no XLIV Congresso da Sociedade Brasileira de Economia e Sociologia Rural. Fortaleza, 23-27 de julho.

DAGNINO, Evelina. (2002), "Sociedade Civil, Espaços Públicos e a Construção Democrática no Brasil: Limites e Possibilidades", in E. Dagnino (org.), Sociedade Civil e Espaços Públicos no Brasil. São Paulo, Paz e Terra, pp. 279-301.

, OLVERA, Alberto J. e PANFICHI, Aldo. (orgs.). (2006), A Disputa pela Construção Democrática na América Latina. São Paulo/Campinas, Paz e Terra/Unicamp.

DELGADO, Nelson, BONNAL, Philippe, LEITE, Sergio e KATO, Karina. (2008), Desenvolvimento Territorial: Articulação de Políticas e Atores Sociais. Relatório de Pesquisa. Rio de Janeiro, OPPA/CPDA/UFRRJ-IICA/Fórum DRS.

DELGADO, Nelson e ZIMMERMANN, Silvia. (2010), Gestão de Políticas Públicas de Desenvolvimento Rural no Contexto das Novas Institucionalidades. Relatório 4: Território da Cidadania do Baixo Amazonas/PA. Rio de Janeiro, IICA-OPPA/ CPDA/UFRRJ.

(2009), Gestão de Políticas Públicas de Desenvolvimento Rural no Contexto das Novas Institucionalidades. Relatório 3: Território da Cidadania Noroeste Colonial RS. Rio de Janeiro, IICA-OPPA/CPDA/UFRRJ.

. (2008a), Gestão de Políticas Públicas de Desenvolvimento Rural no Contexto das Novas Institucionalidades. Relatório 1: Os Programas Territórios da Cidadania e Térritórios Rurais de Identidade. Reflexões Metodológicas sobre Institucionalidades Territoriais e Gestão de Políticas Públicas. Rio de Janeiro, OPPA/CPDA/ UFRRJ-IICA..

( 2008 b), Gestão de Políticas Públicas de Desenvolvimento Rural no Contexto das Novas Institucionalidades. Relatório 2: Território da Cidadania da Borborema PB. Rio de Janeiro, OPPA/CPDA/UFRRJ-IICA.

ECHEVERRI, Rafael. (2009), Identidade e Território no Brasil. Brasília, IICA.

FAVARETO, Arilson. (2008), Três Instantâneos sobre a Gestão Social do Desenvolvimento Territorial nos Anos 2000: Notas para um Balanço. Trabalho apresentado no III Fórum Internacional de Desenvolvimento Territorial. IICA/Fórum DRS/MDA, Fortaleza, 5-7 de novembro.

FLEXOR, Georges e LEITE, Sergio. (2007), “Análise das Políticas Públicas: Breves Considerações Teórico-Metodológicas", in E. N. Fatima et alii (orgs.), Mundo Rural IV: Configuração Rural-Urbans: Poderes e Políticas. Rio de Janeiro, Mauad.

FREY, Klaus. (2000), “Políticas Públicas: Um Debate Conceitual e Reflexões Referentes à Prática da Análise de Políticas Públicas no Brasil". Planejamento e Políticas Públicas, no 21.

HIRSCHMAN, Albert O. (1984), Getting ahead Collectively. New York, IAF.

LEITE, Sergio; KATO, Karina e ZIMMERMANN, S. (2009), Gestão Social dos Territórios. Rio de Janeiro, CPDA/UFRRJ-OPPA-IICA. (Relatório Final) 


\section{Nelson Giordano Delgado e Sergio Pereira Leite}

OFFE, Claus. (2001), “A Atual Transição da História e algumas Opções Básicas para as Instituições da Sociedade", in L. C. Bresser-Pereira, J. Wilheim e L. Sola (orgs.), Sociedade e Estado em Transformação. São Paulo/Brasília, Ed. Unesp/ENAP, pp. 119-145.

SANTOS, Maria Helena C. (1997), “Governabilidade, Governança e Democracia: Criação da Capacidade Governativa e Relações Executivo-Legislativo no Brasil pósConstituinte". DADOS, vol. 40, no 3 .

SENRA, K.V. (2007), Desenvolvimento e Território. Pesquisa Exploratória sobre Políticas e Instituições para Desenvolvimento Econômico Territorial - DET. O Caso do Brasil. Santiago, CEPAL-ILPES/GTZ, Versão Preliminar.

VEIGA, José E. da. (2006), “Potencial de Cooperação e Articulação no Desenvolvimento Rural". Cadernos do CEAM, ano V, no 23, pp. 221-278. 


\section{ABSTRACT \\ Territorial Development Policies in the Brazilian Countryside: New Institutional Arrangements and Key Protagonists}

This article analyzes the implementation of two policies for territorial development of the Brazilian countryside in the first decade of the $21^{\text {st }}$ century: the Program for the Sustainable Development of Rural Territories (Pronat) and the Program for Territories of Citizenship (PTC). Examining the new institutional arrangements, the programs' social management and governance structures, and the protagonist role of the various stakeholders, the article concludes that to a certain extent the programs represent a unique strategy for political action and development in the respective geographic areas. However, they still face enormous challenges for effective consolidation of their results.

Key words: territorial development; public policies; rural territories; territories of citizenship; Brazilian countryside

\section{RÉSUMÉ}

Politiques de Développement du Territoire en Milieu Rural au Brésil: Les Nouvelles Pratiques Institutionnelles et le Rôle des Acteurs

Dans cet article, on examine la mise en place de deux politiques orientées vers le développement du territoire en milieu rural au Brésil dans les années 2000: le Programme de Développement Durable des Territoires Ruraux (Pronat) et le Programme Territoires de la Citoyenneté (PTC). D'après l'examen des nouvelles pratiques institutionnelles en cours, de la gestion sociale des programmes et de leurs structures de gouvernance, ainsi que du rôle des acteurs engagés, on conclut que ces derniers ont suivi, d'une certaine façon, une stratégie singulière $\mathrm{d}^{\prime}$ action politique pour le développement des régions concernées, malgré les immenses enjeux à venir, afin d'aboutir à des résultats vraiment solides.

Mots-clés: développement du territoire; politiques publiques; territoires ruraux, territoires de la citoyenneté; milieu rural au Brésil 